\title{
Effects of Different Mutagenic Chemicals on Callogensis in Sugarcane (Saccharum officinarum) Clones 2008T42 and 2009T5
}

\author{
S. J. Mallikarjuna*, M. Hemath Kumar, D. Mohan Reddy and P. Sudhakar \\ Department of Genetics and Plant Breeding, S.V. Agricultural College, \\ Tirupati-517502, India \\ *Corresponding author
}

\section{A B S T R A C T}

\begin{tabular}{|l|}
\hline Ke y w or d s \\
$\begin{array}{l}\text { Sodium nitrite, EMS, } \\
\text { Leaf rolls, Callus } \\
\text { induction }\end{array}$ \\
\hline Article Info \\
\hline $\begin{array}{l}\text { Accepted: } \\
\text { 15 May } 2018 \\
\text { Available Online: } \\
\text { 10 June } 2018\end{array}$ \\
\hline
\end{tabular}

\section{Introduction}

Sugarcane (Saccharum officinarum L.) is one of the economically important crops widely cultivated in the tropics to subtropics and annually provides around 60 to $70 \%$ of the world's sugar (Shah et al., 2009). Unfortunately, the production of this crop retained by several biotic and abiotic stresses such as bacterial and fungal diseases, drought, salinity, freezing etc. The improvement of sugarcane plant resistance to these stresses is of great importance. Genetic potential of a variety plays an important role in determining the stress resistance, yield and quality of it. Genetic variability is the key factor in any breeding method. The genetic variability created through conventional breeding techniques is slow and depend on recombination (Mascarenhas, 1991).

In conventional breeding method, development of elite sugarcane cultivars with high sugar yield and disease resistance are often defeated by tight linkage between cane quality, cane yield and disease resistance etc. The developments in plant tissue culture have opened up new possibilities in creating genetic variability. The use of tissue culture for creation of somaclonal variation can be used to increase the speed of efficiency of the breeding process to improve the accessibility of existing germplasm of sugarcane and create new variation for crop improvement. 
Mutagenesis refers to the artificial induction of genetic variation via the use of physical or chemical mutagens (Drake and Koch, 1976). It was first carried out using X-rays in the fruit fly, Drosophila spp., by Muller in 1927 (Van Harten, 1998). In plants, various methods which include heat treatment, centrifugation and ageing of seeds, were initially carried out in an attempt to induce mutations (Van Harten, 1998). Ionizing radiation, X-rays, gamma rays and thermal neutrons were later used, but the first attempts resulted in low mutation frequencies and lethal effects on the plants, which were resolved by improving treatment conditions (Novak and Brunner, 1992 and Brunner, 1995). The mechanisms that result in mutations during induced mutagenesis are similar to those that result in spontaneous mutations during in vitro culture (Jain et al., 1998). However, the frequency of mutagen-induced mutations is higher than that of spontaneous mutations in in vitro culture (Novak and Brunner, 1992). Obtaining desired mutations through the use of mutagens is based on chance and may also result in lethal effects that can disrupt normal plant development (Roane, 1973).

\section{Materials and Methods}

\section{Plant Material}

Pre-release sugarcane clones, 2008T42 (mid late) and 2009T5 (early) were chosen for the present investigation (fig no 1). The plants were raised and maintained under field conditions as per the recommended agronomic practices. These plants served as the source of explants for all the in vitro studies conducted during the course of investigation.

\section{Culture conditions}

The cultures were incubated in a culture room maintained at a temperature of $25 \pm 2^{\circ} \mathrm{C}$, relative humidity of 70 per cent and 16 hours of photoperiod with light intensity of 2500 lux. Subcultures were done for every 2-3 weeks according to the need of the experiment.

\section{Somaclonal Induction}

Callus culture was initiated from the innermost leaves and leaf sheaths surrounding the apical meristem of 6 months old field grown 2008T42 and 2009T5. The young leaf bits were inoculated with MS basal medium (Murashige and Skoog, 1962) supplemented with $4 \mathrm{mg} \mathrm{l}^{-1} 2$, 4-Dichlorophenoxyacetic acid (2, 4-D) along with different levels of concentrations of mutagenic chemicals (Sodium nitrite and EMS) on induction of somaclones (Table 1). The medium was solidified with $0.8 \%$ agar (Hi media). The $\mathrm{pH}$ was subjected to 5.8. For the induction of callus the cultures were inoculated in dark. The callus was subcultured three to four times at 15 days interval.

In order to study the effects of different levels of concentrations of mutagenic chemicals on induction of callus different treatments were developed as follows.

\section{Results and Discussion}

Treatmental differences were significant for number of days for callus initiation. Time taken for callus initiation ranged from 12.2 to 16.5 days when the medium was treated with different concentrations of sodium nitrite and EMS (Table 4.2). The no. of days for callus initiation in controls are 9.7 (2008T42) and 10.2 (2009T5). Maximum number of days (16.5) taken for callus initiation was recorded with $7 \mathrm{mg} \mathrm{l}^{-1}\left(\mathrm{~T}_{3}\right)$ followed by 16.1 days with $5 \mathrm{mg} \mathrm{l}^{-1}\left(\mathrm{~T}_{2}\right)$ in $\mathrm{SN}$ treatments (Plate no.2). Whereas minimum number of days (12.2) for callus initiation was recorded with $0.6 \mu \mathrm{M}$ $\left(\mathrm{T}_{7}\right)$ followed by 12.3 days with $0.8 \mu \mathrm{M}\left(\mathrm{T}_{8}\right)$ in EMS treatments $\left(\mathrm{T}_{8}\right)$. With respect to 
sodium nitrate maximum number of days taken for callus initiation was observed with 7 $\mathrm{mg} \mathrm{l}^{-1}$ in 2008T42 $\left(\mathrm{T}_{3}\right)$ followed by $5 \mathrm{mg} \mathrm{l}^{-1}$ $\left(\mathrm{T}_{2}\right)$ in 2008T42 and minimum with $3 \mathrm{mg} \mathrm{l}^{-1}$ in 2009T5 $\left(\mathrm{T}_{4}\right)$ followed by $5 \mathrm{mg} \mathrm{l}^{-1}$ in $\left(\mathrm{T}_{5}\right)$ in 2009T5 (Plate no.2). With respect to EMS, 1.0 $\mu \mathrm{M}$ in 2009T5 $\left(\mathrm{T}_{12}\right)$ recorded maximum number of days for callus initiation followed by $0.8 \mu \mathrm{M}$ in 2009T5 $\left(\mathrm{T}_{11}\right)$ and minimum with $0.6 \mu \mathrm{M}$ in $2008 \mathrm{~T} 42\left(\mathrm{~T}_{7}\right)$ followed by $0.8 \mu \mathrm{M}$ in 2008T42 $\left(\mathrm{T}_{8}\right)$ (Plate.no. 1). Both the clones took minimum number of days for callus initiation with $3 \mathrm{mg} \mathrm{l}^{-1} \mathrm{SN}$ and $0.6 \mu \mathrm{M}$ BMS. Increase in the concentration of two mutagens delayed the time taken for callus initiation.

The mean number of explants inducing callus for different concentrations of sodium nitrite and EMS ranged from 3.67 to 5.67 (Table 1) as against 6.00 in the both controls, $2008 \mathrm{~T} 42$ $\left(\mathrm{C}_{1}\right)$ and $2005 \mathrm{~T} 9\left(\mathrm{C}_{2}\right)$. Significant differences among treatments were observed.

Maximum mean number of explants induced callus (5.67) was recorded with $3 \mathrm{mg} \mathrm{l}^{-1}$ of sodium nitrate $\left(\mathrm{T}_{4}\right)$ followed by 5.33 with 0.6 $\mu \mathrm{M}$ of EMS $\left(\mathrm{T}_{10}, \mathrm{~T}_{7}\right)$ and $3 \mathrm{mg} \mathrm{l}^{-1}$ of sodium nitrate $\left(\mathrm{T}_{1}\right)$ and minimum was recorded as 3.67 with $7 \mathrm{mg} \mathrm{l}^{-1}$ of sodium nitrate $\left(\mathrm{T}_{6}\right)$ followed by 4.00 with $7 \mathrm{mg} \mathrm{l}^{-1}$ of sodium nitrate $\left(\mathrm{T}_{3}\right)$ in both sugarcane clones of 2008T42 and 2005T5.

With respect to sodium nitrate for both clones, 2009T5 recorded maximum mean number of explants induced callus (5.67) at $3 \mathrm{mg} \mathrm{l}^{-1}\left(\mathrm{~T}_{4}\right)$ followed by $2008 \mathrm{~T} 42(5.33)$ at $3 \mathrm{mg} \mathrm{l}^{-1}\left(\mathrm{~T}_{1}\right)$ concentration and minimum mean number of explants induced callus was observed in $2009 \mathrm{~T} 5$ (3.67) with $7 \mathrm{mg} \mathrm{l}^{-1}\left(\mathrm{~T}_{6}\right)$ followed by 2008T42 (4.00) at $7 \mathrm{mg} \mathrm{l}^{-1}\left(\mathrm{~T}_{3}\right)$ (Plate no.2). With respect to EMS, both clones recorded maximum mean number of explants induced callus (5.33) at $0.6 \mu \mathrm{M}\left(\mathrm{T}_{7}, \mathrm{~T} 10\right)$ followed by 2009T5 (5.00) with $0.8 \mu \mathrm{M} \quad\left(\mathrm{T}_{11}\right)$ and minimum was observed with $1.0 \mu \mathrm{M}\left(\mathrm{T}_{9}\right)$ in
$2008 \mathrm{~T} 42$ (4.00) followed by $2008 \mathrm{~T} 42$ (4.33) and 2009T5 (4.33) with $0.8 \mu \mathrm{M}\left(\mathrm{T}_{8}\right)$ and 1.0 $\mu \mathrm{M}\left(\mathrm{T}_{12}\right)$ concentrations respectively (Plate no.1).

The treatments differed significantly for callus induction frequency. Callus induction frequency ranged from 63.44 to $91.59 \%$ for different concentrations of sodium nitrite and EMS in both the clones. It was $100 \%$ in both the controls. Maximum callus induction frequency $(91.59 \%)$ was recorded with $3 \mathrm{mg} \mathrm{l}^{-}$ ${ }^{1}$ of sodium nitrate $\left(\mathrm{T}_{4}\right)$ followed by $88.52 \%$ with $3 \mathrm{mg} \mathrm{l}^{-1}$ of sodium nitrate $\left(\mathrm{T}_{1}\right)$ and the minimum was recorded as $63.44 \%$ with $7 \mathrm{mg}$ $1^{-1}$ of sodium nitrate $\left(\mathrm{T}_{6}\right)$ followed by $67.64 \%$ with $1.0 \mu \mathrm{M}$ of EMS $\left(\mathrm{T}_{9}\right)$. With respect to sodium nitrate, 2009T5 recorded maximum callus induction frequency $(91.59 \%)$ at $3 \mathrm{mg} \mathrm{l}^{-}$ ${ }^{1}\left(\mathrm{~T}_{4}\right)$ followed by $2008 \mathrm{~T} 42(88.52 \%)$ at $3 \mathrm{mg}$ $1^{-1}\left(\mathrm{~T}_{1}\right)$ concentration and minimum callus induction frequency was observed in 2009T5 $(63.44 \%)$ with $7 \mathrm{mg}^{-1}\left(\mathrm{~T}_{6}\right)$ followed by $2008 \mathrm{~T} 42(67.72 \%)$ at $7 \mathrm{mg} \mathrm{l}^{-1}\left(\mathrm{~T}_{3}\right)$ (Plate.no.2). In case of EMS, the genotype, 2009T5 recorded maximum callus induction frequency $(87.03 \%)$ at $0.6 \mu \mathrm{M}\left(\mathrm{T}_{10}\right)$ followed by $2008 \mathrm{~T} 42(85.63 \%)$ with $0.6 \mu \mathrm{M}\left(\mathrm{T}_{7}\right)$ and minimum callus induction frequency was observed with $1.0 \mu \mathrm{M}\left(\mathrm{T}_{9}\right)$ in 2008T42 $(67.64 \%)$ followed by $2008 \mathrm{~T} 42(71.06 \%)$ with $0.8 \mu \mathrm{M}\left(\mathrm{T}_{8}\right)$ (Plate.no.1).

The mean callus size was estimated as 2.8 and $3.0 \mathrm{~cm}$ in controls, 2008T42 $\left(\mathrm{C}_{1}\right)$ and 2005T9 $\left(\mathrm{C}_{2}\right)$, respectively. The mean callus size ranged from $1.1-2.3 \mathrm{~cm}$ for different concentrations of sodium nitrite and EMS (Table 1). Differences among treatments were significant. Maximum mean callus size (2.3 $\mathrm{cm})$ was recorded with $0.6 \mu \mathrm{M}$ of EMS $\left(\mathrm{T}_{10}\right)$ followed by $2.1 \mathrm{~cm}$ with $0.6 \mu \mathrm{M}$ of EMS $\left(\mathrm{T}_{7}\right)$ and the minimum was recorded as $1.1 \mathrm{~cm}$ with $7 \mathrm{mg} \mathrm{l}^{-1}$ of sodium nitrate $\left(\mathrm{T}_{6}\right)$ followed by 1.2 $\mathrm{cm}$ with $1.0 \mu \mathrm{M}$ of EMS $\left(\mathrm{T}_{9}\right)$ and $7 \mathrm{mg} \mathrm{l}^{-1}$ of sodium nitrate $\left(\mathrm{T}_{3}\right)$. 
Table.1a

\begin{tabular}{|c|c|c|c|}
\hline Treatments & Variety & $\begin{array}{l}\text { MS media + } 4 \mathrm{mg} \mathrm{l}^{-1} 2,4-D+ \\
\text { Sodium nitrite }\left(\mathrm{mg} \mathrm{l}^{-1}\right)\end{array}$ & $\begin{array}{c}\text { MS media + 4 } \mathrm{mg} \mathrm{l}^{-1} 2,4-\mathrm{D} \\
+\mathrm{EMS}(\mu \mathrm{M})\end{array}$ \\
\hline $\mathbf{T}_{1}$ & $2008 \mathrm{~T} 42$ & 3 & 0 \\
\hline $\mathbf{T}_{2}$ & $2008 \mathrm{~T} 42$ & 5 & 0 \\
\hline $\mathbf{T}_{3}$ & 2008T42 & 7 & 0 \\
\hline $\mathbf{T}_{4}$ & $2009 T 5$ & 3 & 0 \\
\hline $\mathbf{T}_{5}$ & 2009T5 & 5 & 0 \\
\hline$T_{6}$ & 2009T5 & 7 & 0 \\
\hline $\mathbf{T}_{7}$ & $2008 \mathrm{~T} 42$ & 0 & 0.6 \\
\hline $\mathbf{T}_{8}$ & 2008T42 & 0 & 0.8 \\
\hline $\mathrm{T}_{9}$ & 2008T42 & 0 & 1.0 \\
\hline $\mathbf{T}_{10}$ & 2009 T5 & 0 & 0.6 \\
\hline $\mathbf{T}_{11}$ & 2009 T5 & 0 & 0.8 \\
\hline $\mathbf{T}_{12}$ & 2009 T5 & 0 & 1.0 \\
\hline$\overline{\mathrm{C}_{1}}$ & $2008 \mathrm{~T} 42$ & 0 & 0 \\
\hline $\mathrm{C2}$ & $2009 T 5$ & 0 & 0 \\
\hline
\end{tabular}

Table.1b Effect of different concentrations of mutagenic chemicals on callusing in two sugarcane clones

\begin{tabular}{|c|c|c|c|c|}
\hline Treatments & $\begin{array}{l}\text { Mean no. of } \\
\text { days for } \\
\text { callus } \\
\text { initiation }\end{array}$ & $\begin{array}{l}\text { Mean no. of } \\
\text { explants } \\
\text { induced } \\
\text { callus }\end{array}$ & $\begin{array}{c}\text { Callus } \\
\text { induction } \\
\text { frequency } \\
(\%)\end{array}$ & $\begin{array}{l}\text { Mean } \\
\text { callus size } \\
(\mathrm{cm})\end{array}$ \\
\hline SN $3 \mathrm{mg} \mathrm{I}^{-1} 2008 \mathrm{~T} 42\left(\mathrm{~T}_{1}\right)$ & 15.7 & 5.33 & $88.52(70.17)$ & 1.9 \\
\hline SN $5 \mathrm{mg} \mathrm{l}^{-1} 2008 \mathrm{~T} 42\left(\mathrm{~T}_{2}\right)$ & 16.1 & 5.00 & $83.21(65.78)$ & 1.4 \\
\hline SN $7 \mathrm{mg} \mathrm{l}^{-1} 2008 \mathrm{~T} 42\left(\mathrm{~T}_{3}\right)$ & 16.5 & 4.00 & $67.72(55.35)$ & 1.2 \\
\hline SN $3 \mathrm{mg} \mathrm{l}^{-1} 2009 \mathrm{T5}\left(\mathrm{T}_{4}\right)$ & 13.6 & 5.67 & $91.59(73.14)$ & 2.0 \\
\hline SN $5 \mathrm{mg} \mathrm{l}^{-1} 2009 \mathrm{~T} 5\left(\mathrm{~T}_{5}\right)$ & 14.0 & 5.00 & $81.23(64.32)$ & 1.5 \\
\hline SN $7 \mathrm{mg} \mathrm{l}^{-1} 2009 \mathrm{T5}\left(\mathrm{T}_{6}\right)$ & 15.2 & 3.67 & $63.44(52.77)$ & 1.1 \\
\hline EMS $0.6 \mu \mathrm{M} \mathrm{I}^{-1} 2008 \mathrm{~T} 42\left(\mathrm{~T}_{7}\right)$ & 12.2 & 5.33 & $85.63(67.76)$ & 2.1 \\
\hline EMS $0.8 \mu \mathrm{M} \mathrm{l}^{-1} 2008 T 42\left(\mathrm{~T}_{8}\right)$ & 12.3 & 4.33 & $71.06(57.36)$ & 1.6 \\
\hline EMS $1.0 \mu \mathrm{M} \mathrm{I}^{-1} 2008 \mathrm{~T} 42\left(\mathrm{~T}_{9}\right)$ & 12.7 & 4.00 & $67.64(55.30)$ & 1.2 \\
\hline EMS $0.6 \mu \mathrm{M} \mathrm{l}^{-1} 2009 \mathrm{T5}\left(\mathrm{T}_{10}\right)$ & 13.3 & 5.33 & $87.03(68.89)$ & 2.3 \\
\hline EMS $0.8 \mu \mathrm{M} \mathrm{l}^{-1} 2009 \mathrm{T5}\left(\mathrm{T}_{11}\right)$ & 13.5 & 5.00 & $81.88(64.71)$ & 1.9 \\
\hline EMS $1.0 \mu \mathrm{M} \mathrm{l}^{-1} 2009 \mathrm{~T} 5\left(\mathrm{~T}_{12}\right)$ & 13.7 & 4.33 & $71.11(57.46)$ & 1.6 \\
\hline $2008 T 42$ (Control) $\left(\mathrm{C}_{1}\right)$ & 9.7 & 6.00 & $100.0(90.00)$ & 2.8 \\
\hline $2009 T 5$ (Control) $\left(\mathrm{C}_{2}\right)$ & 10.2 & 6.00 & $100.0(90.00)$ & 3.0 \\
\hline C.D at 5\% & 0.187 & 0.343 & 2.119 & 0.091 \\
\hline$( \pm) \mathrm{SE}(\mathrm{m})$ & 0.064 & 0.118 & 0.728 & 0.031 \\
\hline
\end{tabular}


Plate.1 Callus induction in different concentrations of EMS with controls in sugarcane clone

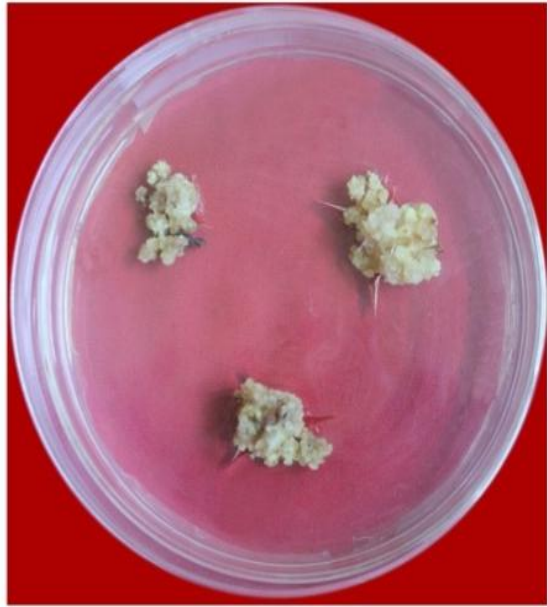

$\mathrm{C}_{1}(2008 \mathrm{~T} 42)$

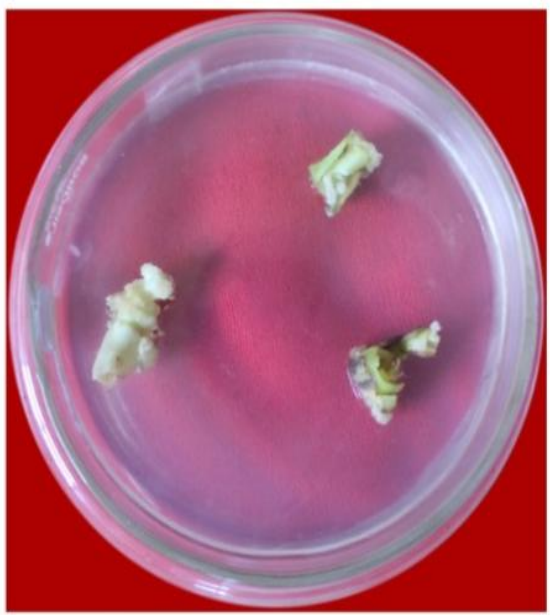

T7 (EMS 0.6 $\mu \mathrm{M} 2008 \mathrm{~T} 42)$

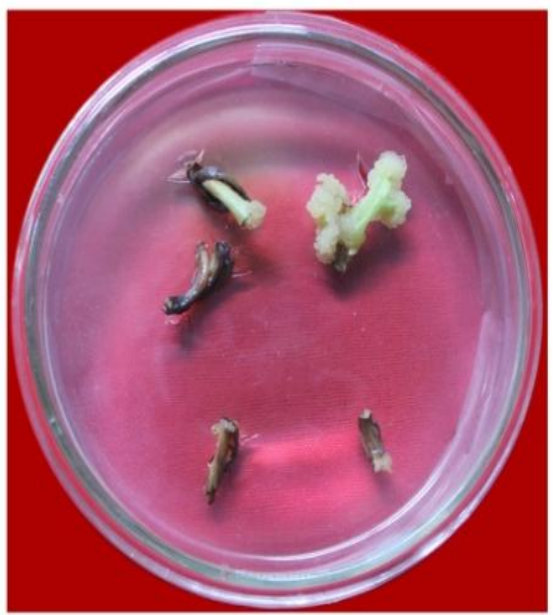

T9(EMS 1.0 $\mu \mathrm{M} 2008 T 42)$

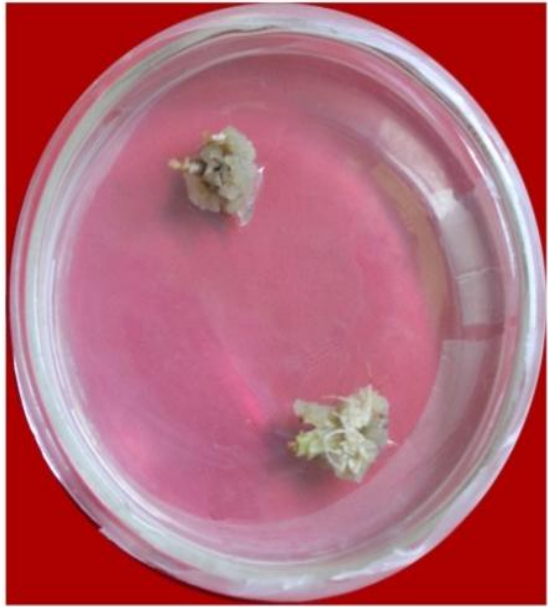

$\mathrm{C}_{2}$ (2009T5)

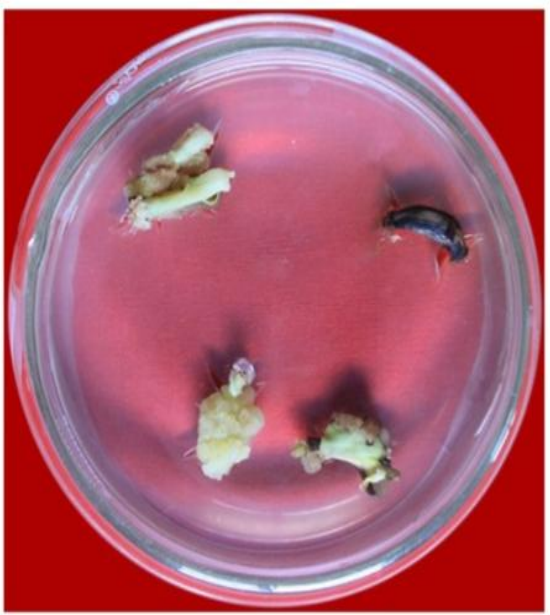

$\mathrm{T}_{10}(\mathrm{EMS} 0.6 \mu \mathrm{M}$ 2009T5)

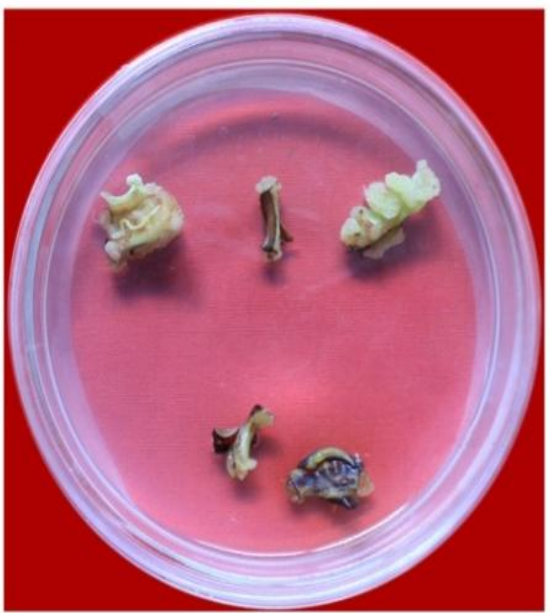

T $_{12}($ EMS 1.0 $\mu$ M 2009T5) 
Plate.2 Callus induction in different concentrations of sodium nitrite with controls in sugarcane clone

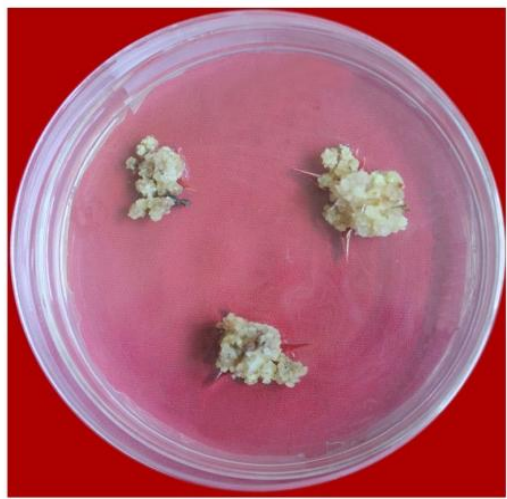

$\mathrm{C}_{1}(\mathbf{2 0 0 8 T 4 2 )}$

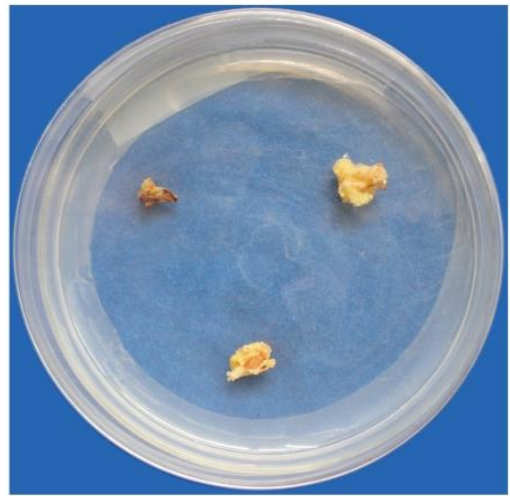

$\mathrm{T}_{1}$ (SN 3mgl-1 ${ }^{-1}$ 2008T42)

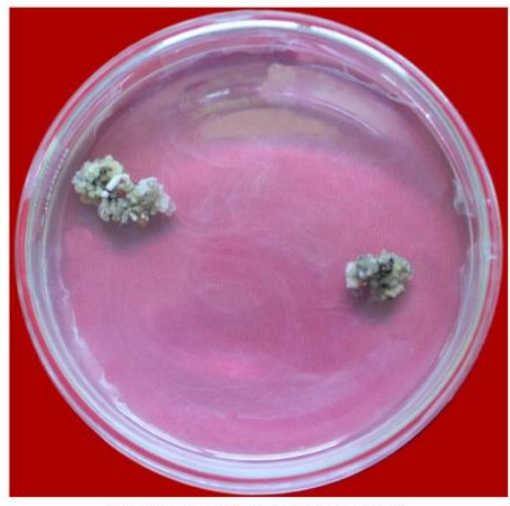

$\mathrm{T}_{3}$ (SN $7 \mathrm{mgl}{ }^{-12008 T 42)}$

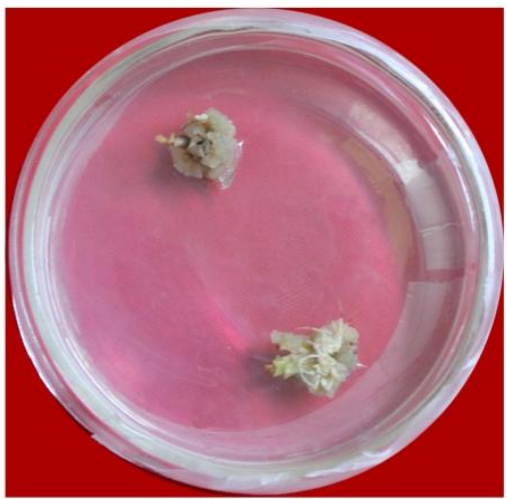

$\mathrm{C}_{2}(\mathbf{2 0 0 9 T 5 )}$

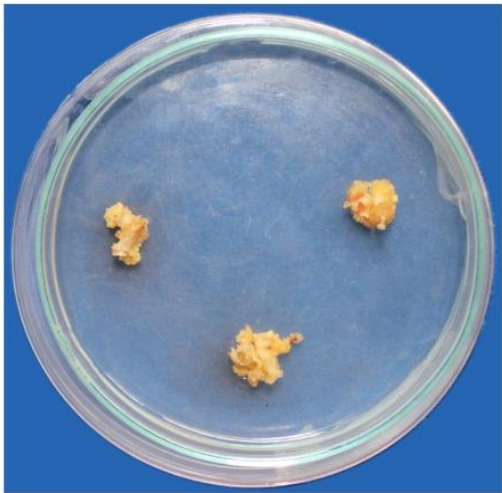

$\mathrm{T}_{4}$ (SN 3mgl-12009T5)

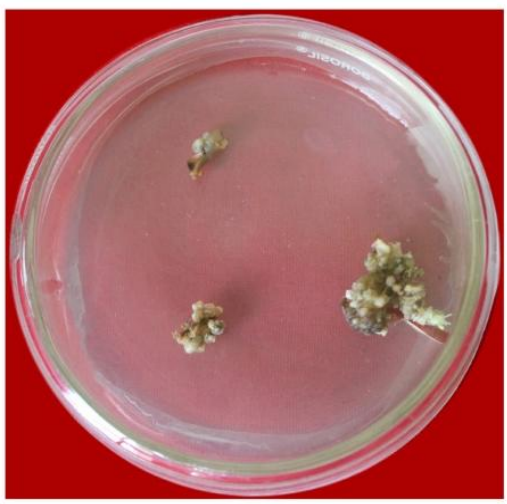

$\mathrm{T}_{6}$ (SN 7mgl-12009T5)

of EMS, 2009T5 recorded maximum mean callus size $(2.3 \mathrm{~cm})$ at $0.6 \mu \mathrm{M}\left(\mathrm{T}_{10}\right)$ followed by $2008 \mathrm{~T} 42(2.1 \mathrm{~cm})$ with $0.6 \mu \mathrm{M}\left(\mathrm{T}_{7}\right)$ and minimum mean callus size was observed with $1.0 \mu \mathrm{M}\left(\mathrm{T}_{9}\right)$ in $2008 \mathrm{~T} 42(1.2 \mathrm{~cm})$ followed by $2008 \mathrm{~T} 42(1.6 \mathrm{~cm})$ and 2009T5 $(1.6 \mathrm{~cm})$ with $0.8 \mu \mathrm{M}\left(\mathrm{T}_{8}\right)$ and $1.0 \mu \mathrm{M}\left(\mathrm{T}_{12}\right)$ concentrations, 
respectively (Plate.no.1). Maximum callus production was observed in the controls and callus production decreased with increase in concentration of mutagenic chemicals. Yasmeen, et al., (2013) and Khan, et al., (2009) reported stimulation in callus growth at lower doses and poor stimulation in high doses of mutagenic chemicals. Bajaj et al., (1970) and Siddiqui \& Javed (1982) also reported stimulation in callus growth at lower doses of gamma irradiation. Callus induction was reported to be cent per cent in controls without EMS and sodium nitrite. Similar kind of results were also reported by Begum et al., (2011). With the increase in the concentration of the mutagen there was an increase in number of days required for the callus initiation. Gahukar and Jambhule (2000) also found similar type of decrease in callus obtained with increased dose of gamma rays and EMS in sugarcane. With the increased level of these chemicals the percentage of callus initiation decreased. This was also supported by Munsamy et al., (2013) and Sung (1976) who had reported a decrease in survival of soybean cell suspension cultures with increasing concentrations of EMS. The callus size also decreased with an increase in concentration of sodium nitrite and EMS in both clones. Similar decrease in callus size was observed by Reddy et al., (1987) in castor bean and by Singh and Singh (1993) in sugarcane with the increase in the dose of gamma irradiation. The present results agree with those reported by Ather et al., (2009), Taghian (1998) and Raza et al., (2010) for sugarcane.

Maximum callus production was observed in the controls and callus production decreased with increase in concentration of mutagenic chemicals. There was an increase in number of days required for callus initiation, a decrease in callus induction frequency and also a decrease in callus size with an increase in concentration of sodium nitrite and EMS in both clones. EMS was proved to produce better response than sodium nitrite in both clones. The results revealed that EMS rather than sodium nitrite was found to have better response for callus induction in both 2008T42 and 2009T5 sugarcane clones. Because EMS showed callus induction with lowest mean number days for callus initiation, maximum number of explants induced callus with highest callus induction frequency and good callus size. In both clones, 2009T5 showed better response in both mutagenic chemicals when compared with 2008T42 callus induction.

\section{References}

Ather, A., Khan, S., Rehman, A and Nazir, M. 2009. Optimization of the protocol for callus induction, regeneration and acclimatization of sugarcane. CV. Thatta10. Pakistan Journal of Botany. 41(2): 815820.

Bajaj, O.M., Nasr, M.I and Alhendawi, R.A. 1970. Response of sugarcane (Saccharum species hybrid) genotypes to embryogenic callus induction and in vitro salt stress. Sugar Technology. 10(3): 243-247.

Begum, M.K., Islam, M.O., Miah, M.A.S., Hossain, M.A and Islam, N. 2011. Production of somaclone in vitro for drought stress tolerant plantlet selection in sugarcane (Saccharum officinarum L.). The Agriculturists. 9(1\&2): 18-28.

Brunner, M. D. 1995. Regeneration and phenotypic variability of plants cultured in vitro from mature sugarcane caryopsis. Journal of American Society of Sugarcane Technology. 12: 82-90.

Drake, J.W. and Koch, R.E. 1976. Mutagenesis. Hutchinson and Ross Publishers, Dowden. Pp: 1-363.

Gahukar, A and Jambhule, P. K. 2000. In vitro selection and characterization of Vigna radiata cell line resistant to PEG induced drought stress. Acta Physiologiae Plantarum. 16(1): 53-60.

Jain, S.M., Brar, D.S and Ahloowalia, B.S. 1998. Somaclonal variation and induced 
mutations in crop improvement. Kluwer academic Publishers, Dordrecht. pp: 1-640.

Khan, S.A., Rashid, H., Chaudhary, M.F., Chaudhry, Z., Fatima, Z., Siddiqui, S.U and Zia, M. 2009. Effect of cytokinins on shoot multiplication in three elite sugarcane varieties. Pakistan J. Bot. 41: 1651-165.

Mascarenhas, A.F. 1991. Hand Book of Plant Tissue culture, ICAR Publications, New Delhi.

Munsamy, A., Rutherford, R., Snyman, S and Watt, M. 2013. 5-Azacytidine as a tool to induce somaclonal variants with useful traits in sugarcane (Saccharum spp.). Plant Biotechnology Reports. 7(4): 489.

Murashige, T and Skoog, F. 1962. A revised medium for rapid growth and biossays with tobacco cultures. Physiology Plantarum. 15: 473-497.

Novak. F.J and Brunner, H. 1992. Plant breeding: Induced mutation technology for crop improvement. IAEA Bulletin. 4: 25-33.

Raza, G., Ali, K., Mukhtar, Z., Mansoor, S., Arshad, M and Asad, S. 2010. The response of sugarcane (Saccharum officinarum L.) genotypes to callus induction, regeneration and differentlconcentrations of the selective agent (geneticin-418). African Journal of Biotechnology. 9(51): 8739-8747.

Reddy, K.R.K., Rao, G.P., Malathi, $\mathrm{N}$ and Bahadur, B. 1987. Effect of gamma irridation on growth and phenolic production in castor bean cultures. Curr. Sci. 56(23): 1234-1235.

Roane, C.W. 1973. Trends in breeding for disease resistance in crops. Annual Review of Phytopathology. 11: 463-486.

Shah, A.H., Rashid, N., Haider, M.S., Saleem, F., Tahir, M and Iqbal, J. 2009. An efficient short and cost effective regeneration system for transformation studies of sugarcane (Saccharum officinarum L.). Pak. J. Bot. 42(2):609-614.

Shamim, H., Siddiqui, Abdullah Khatri, Imtiaz A. Khan, Muhammad Aslam Javed, Nazir Ahmed Dahar and Ghulam Shah Nizamani. 1994. In vitro culture: a source of genetic variability and an aid to sugarcane improvement. Pakistan J. Agric. Res. 15(1): 256-284.

Siddiqui, N.M and Javed, K.L. 1982. Tissue culture of cereal cultivars with increased salt, drought and acid tolerance. Proceedings of the Biotechnology in International Agricultural Research Conference, BIARC'1985, IRRI, Philippines. 121-138.

Singh, S.K and Singh, S.B. 1993. Effect of gamma rays on callus growth and plant regeneration in sugarcane CV Co 687. Indian Sugar. 43(3): 181-182.

Sung, N. 1976. Smut disease assessment by PCR and microscopy in inoculated tissue cultured sugarcane cultivars. Plant Science. 167: 987-994.

Taghian, A.S. 1998. Genetical studies on sugarcane plants derived from Tissue culture. Assist J Agric Sci. 29(1):113-131.

Van Harten, A.M. 1998. Mutation breeding: Theory and practical applications. Cambridge University Press, London. Pp. 1-34.

Yasmeen, S., Imtiaz, A.K., Abdullah, K., Nighat, S.M., Aquil, S and Sajida, B. 2013. Plant regeneration from irradiated embryogenic callus of sugarcane. Pak. J. Bot. 43(5): 2423-2426.

\section{How to cite this article:}

Mallikarjuna S. J., M. Hemath Kumar, D. Mohan Reddy and Sudhakar P. 2018. Effects of Different Mutagenic Chemicals on Callogensis in Sugarcane (Saccharum officinarum) Clones 2008T42 and 2009T5. Int.J.Curr.Microbiol.App.Sci. 7(06): 1404-1411.

doi: https://doi.org/10.20546/ijcmas.2018.706.167 